\title{
Variation in the composition and content of ellagitannins in the heartwood of European oaks (Quercus robur and $Q$ petraea). A comparison of two French forests and variation with heartwood age
}

\author{
JR Mosedale ${ }^{*}$, B Charrier², N Crouch ${ }^{3}$, G Janin ${ }^{4}$, PS Savill1 \\ ${ }^{1}$ Department of Plant Sciences, Oxford Forestry Institute, \\ University of Oxford, South Parks Road, Oxford OX1 3RB, UK; \\ ${ }^{2}$ École supérieure du bois, CP 3029, rue Christian-Pauc, 44087 Nantes cedex 03, France; \\ ${ }^{3}$ Dyson Perrins Laboratory, University of Oxford, South Parks Road, Oxford OX1 3QY, UK; \\ ${ }^{4}$ Station de recherches sur la qualité des bois, Inra, 54280 Champenoux, France
}

(Received 3 March 1995; accepted 28 July 1995)

\begin{abstract}
Summary - The ellagitannin concentration was measured in water extracts of different heartwood sections of Pressler cores from three Russian and one English Quercus robur tree. As the heartwood age increased, the concentration of total soluble ellagitannins showed a logarithmic decline, while individual ellagitannins varied in their response. A simple model relating the total soluble ellagitannins and heartwood age was calculated. In a second study two heartwood samples were taken from each of 20 oak trees ( $Q$ robur and $Q$ petraea) from each of two contrasting (Limousin and Tronçais) French forests. Over $70 \%$ of the total variation in the concentration of water soluble ellagitannins and total phenolics extracted from the samples was attributed to differences between forests, while relatively little variation occurred between the two within-tree samples. Lower concentrations were found in more slowly grown timber from the Tronçais forest than in wood from the Limousin region. The different tannin concentrations could not be explained solely by the greater heartwood age of Tronçais samples if one assumed that the rate of ellagitannin decline with heartwood age was similar in all trees. A correlation between wood colour, as defined by CIELab colour parameter hue, colour saturation and $\mathbf{b}^{\star}$ (representing colour along the blue-yellow axis), and total phenolics and soluble tannins was also observed. The two forests differed in many regards, including environmental conditions, silvicultural practices and the dominant species.
\end{abstract}

Quercus robur / Quercus petraea / CIELab colour / ellagitannins / heartwood age

Résumé - Variation de la composition et de la teneur en ellagitannins dans le bois de cœur des chênes européens (Quercus robur, $Q$ petraea). Comparaison de deux forêts françaises et variations en fonction de l'âge du bois de cœur. La concentration des ellagitannins a été mesurée dans les extraits acqueux des différentes parties du bois de cœur de carottes de sondage provenant de trois chênes (Quercus robur) prélevés en Russie et un prélevé en Angleterre. La concentration des ellagitanins solubles totaux présentait une diminution logarithmique au fur et à mesure que l'âge du bois augmentait, tandis que les divers ellagitanins présentaient des teneurs variables. Un modèle simple reliant la concentration en ellagitanins solubles totaux avec l'âge a été établi. Dans une étude 
ultérieure, deux échantillons de bois de coeur provenant chacun de 20 chênes européens ( $Q$ robur et $Q$ petraea) issus chacun de deux forêts françaises très différentes (Limousin et Tronçais). Plus de $70 \%$ de la variation totale de la concentration en ellagitanins solubles extraits de ces échantillons a été attribuée à la différence entre les forêts, tandis qu'une relativement faible variation pouvait être attribuée aux deux échantillons prélevés à l'intérieur de chaque arbre. Les teneurs en tanins solubles étaient plus faibles chez les arbres provenant de la forêt Tronçais que chez ceux de la région du Limousin, et ceci ne pouvait pas être expliqué seulement par les légères différences d'âge du bois de cœur des échantillons. Une corrélation entre la couleur du bois, mesurée dans le système CIELab avec les paramètres de teinte (h), de saturation (C) et la coordonnée chromatique $\left(b^{*}\right)$, la teneur en phénols totaux et les tanins solubles a été aussi observée. Les deux forêts présentaient bien des différences du point de vue de l'environnement, des traitements sylvicoles et des dominances d'espèces.

Quercus robur / Quercus petraea / couleur CIELab / ellagitanins / âge du bois de cœur

\section{INTRODUCTION}

The hydrolyzable tannins have been estimated to comprise up to $10 \%$ of the dry weight of heartwood of European oak (Scalbert et al, 1988).

Numerous studies have reported how the concentration of soluble tannins declines as the age of the heartwood increases, away from the sapwood boundary towards the pith of trees (Peng et al, 1991; Klumpers et al, 1994; Viriot et al, 1994; Charrier et al, 1995). However, Viriot et al (1994) reported how the concentration of individual ellagitannins responded in different ways to heartwood age. They proposed a series of reactions as occurring during heartwood ageing. During the first 30 years of ageing, there is conversion from monomeric to dimeric tannins. Hydrolysis reactions occur throughout heartwood ageing at a slow rate estimated as $1 \%$ of the total every 10 years. However, the polymerization of ellagitannins into larger polyphenols is thought to be the main cause of the decline in soluble tannins as heartwood ages.

Few studies have examined the degree of variation in ellagitannin concentrations that occurs between trees, populations and the two European oak species $Q$ petraea (Matt) and $Q$ robur $L$. Levels of tannins in the heartwood of these two species have been reported to be greater than those found in the heartwood of American white oak such as $Q$ alba $L$ (Rous and Alderson, 1983; Quinn and Singleton, 1985; Miller et al, 1992). There is also a long tradition within the wine- and brandy-making industries that the flavour imparted by oak casks varies according to the geographic origins of the oak wood used in their construction. Although the role of the hydrolyzable tannins in influencing flavour is uncertain (Viriot et al, 1993), it is probable that the concentration and composition of oak wood extract will influence flavour imparted by oak casks. However, as reviewed by Mosedale (1995), numerous factors may influence the extractive properties of oak wood. The few studies that have compared different species or origins of European oak wood have generally failed to control other influencing factors sufficiently (such as wood age and storage conditions) or replication has been insufficient (eg, Puech, 1984; Miller et al, 1992; Marco et al, 1994). Studies of the variability of other wood properties, such as density, have generally concluded that the greatest degree of variation occurs between different trees within a forest and between provenances (Zobel and Talbert, 1984).

The primary aim of this study was to examine the variation in soluble ellagitannins of European oak wood between and within trees felled in two forest coupes. The forests were selected to correspond to two 
opposing types of French oak that are used by the cooperage industry and frequently claimed to have different effects on the flavour of wine and brandy. To determine the relative importance of variation between and within mature trees, additional samples were used to confirm the variation of soluble ellagitannins with heartwood age.

\section{MATERIALS AND METHODS}

\section{Materials}

\section{Variation within trees}

A core was taken with a Pressler borer at breast height from each of four trees of between 100120 years of age. Three of the trees came from an oak forest near Voronezh, Russia, having been collected in May 1993, while the other was from an isolated field boundary oak near Oxford, taken in 1990. All the trees were Quercus robur and displayed regular and rapid growth throughout the core lengths. The cores were cut into different sections according to the age of the heartwood from the heartwood-sapwood boundary: $0-5,6-10,11-20$ yearsand so on in steps of 10 years up to $40-70$ years according to the tree. Wood samples from each zone were ground to less than 100 mesh and soluble ellagitannins measured.

\section{Variation between two forests}

Trees were compared from two forests that typified contrasting types of French oaks used for the construction of casks (table I). The trees felled were of suitably high standards for cooperage. By the choice of two such contrasting sites it was intended to test the hypothesis that it is not feasible to select for cooperage wood with significant differences in wood extractives.
One site was located in a forest near Tronçais, the other in the Limousin region of France. From each of these clear felled sites 20 randomly selected trees, of suitable quality for cooperage, were chosen. During the splitting of logs and cutting of bolts, two staves were removed and used for this study. These staves were cut from the outer heartwood, near the base of north and south facing sides of the bole. Therefore, for each site a total of 40 samples from 20 trees were examined.

The 80 staves were stored for approximately 4 months before a hand-held plane was used to remove shavings from their surfaces that would make up the inner face of a barrel. After removal of the frequently discoloured outer surface of the stave, shavings from the top 1-2 $\mathrm{mm}$ were taken and were then ground (Glen Creston type 14$580 \mathrm{mill}$ ) and air-dried to reduce moisture content to approximately $4 \%$ of dry weight.

\section{Methods}

\section{Determination of soluble ellagitannins}

The concentration of soluble ellagitannins extracted from samples of each French oak stave and of each heartwood age zone from the four Pressler cores was measured. The ellagitannins were extracted from $50 \mathrm{mg}$ of wood over a period of $24 \mathrm{~h}$ at room temperature with $5 \mathrm{~mL}$ of the extracting solution: methanol/ $/ \mathrm{H}_{2} \mathrm{O} / \mathrm{H}_{3} \mathrm{PO}_{4} 2 / 97 / 1$ $\mathrm{v} / \mathrm{v} / \mathrm{v}$, with $100 \mathrm{mg} / \mathrm{L}$ of pyrogallol used as the internal standard. After filtration the concentration of ellagitannins was determined by high performance liquid chromatography (HPLC). The solvent system allowed direct injection without further analytical steps and was found to give better separation of early peaks than solvents containing higher proportions of methanol.

Column: Waters reverse-phase $\mathrm{C} 18 ; 260 \times 4 \mathrm{~mm}$; Spherisorb packing. Injection volume: 20 I. Detection: at $230 \mathrm{~nm}(190-400 \mathrm{~nm}$ for dentification).

Table I. Characteristics of Limousin and Tronçais forests from which sample trees derived.

\begin{tabular}{lll} 
& Limousin & Tronçais \\
\hline Forest ownership & Private & State owned and managed \\
Silviculture & Intense thinning and rapid growth & Managed for slow, regular growth \\
Soil type & Heavy, clay soil & Sandy more acidic soil \\
Tree age & 100 years & 180 years \\
Dominant species & Quercus robur & Quercus petraea \\
\hline
\end{tabular}


Internal standard: pyrogallol (Aldrich) at $100 \mathrm{mg} / \mathrm{L}$ extraction solution. Gradient. The following solutions were used: $\mathrm{H}_{2} \mathrm{O} / \mathrm{H}_{3} \mathrm{PO}_{4} 99 / 1 \mathrm{v} / \mathrm{v}$ (solvent A); $\mathrm{MeOH} / \mathrm{H}_{3} \mathrm{PO}_{4} 99 / 1 \mathrm{v} / \mathrm{v}$ (solvent $\mathrm{B}$ ). The best separation of ellagitannins was obtained using a linear gradient from 0 to $9 \%$ of solvent $B$ over $40 \mathrm{~min}$.

\section{Identification and calibration}

Using the criteria suggested by Scalbert et al (1990), that ellagitannins have near identical absorption spectra with no maxima between 240$400 \mathrm{~nm}$ but a shoulder around $280 \mathrm{~nm}, 12$ possible ellagitannins were identified. Acomparison of the relative retention times with results described in earlier studies (Scalbert et al, 1988; Viriot et al, 1994) allowed the identification of nine of these 12 ellagitannins (fig 1). Purified samples of vescalagin, castalagin, grandinin and roburin A (kindly provided by Dr Scalbert, INRA, Paris) allowed confirmation of their identification and were used for calibration.

\section{Measurement of total phenolics}

Folin Denis reagent (AOAC, 1984, 1990; Scalbert, 1992) was used to measure the total phenolics in the extracts of the 80 French oak samples. One $\mathrm{mL}$ of Folin Denis reagent (Fisons diluted $1: 4$ with water), was added to $1 \mathrm{~mL}$ of the extraction solution followed by $1 \mathrm{~mL}$ of a $3 \%$ sodium carbonate solution. After agitation, the samples were placed in a water bath at $50^{\circ} \mathrm{C}$ for $20 \mathrm{~min}$. After cooling for $5 \mathrm{~min}$, absorbance at $760 \mathrm{~nm}$ was measured. Calibration of the spectrophotometer was performed for each batch of samples using gallic acid (Aldrich) solutions and the results were expressed as gallic acid equivalents (GAE). Extract solutions were suitably diluted, typically by $1: 5$ with water.

\section{Insoluble ellagitannins}

Insoluble ellagitannins in wood can be estimated by degradation in alcohol-hydrochloric acid solutions measuring the resulting ellagic acid by

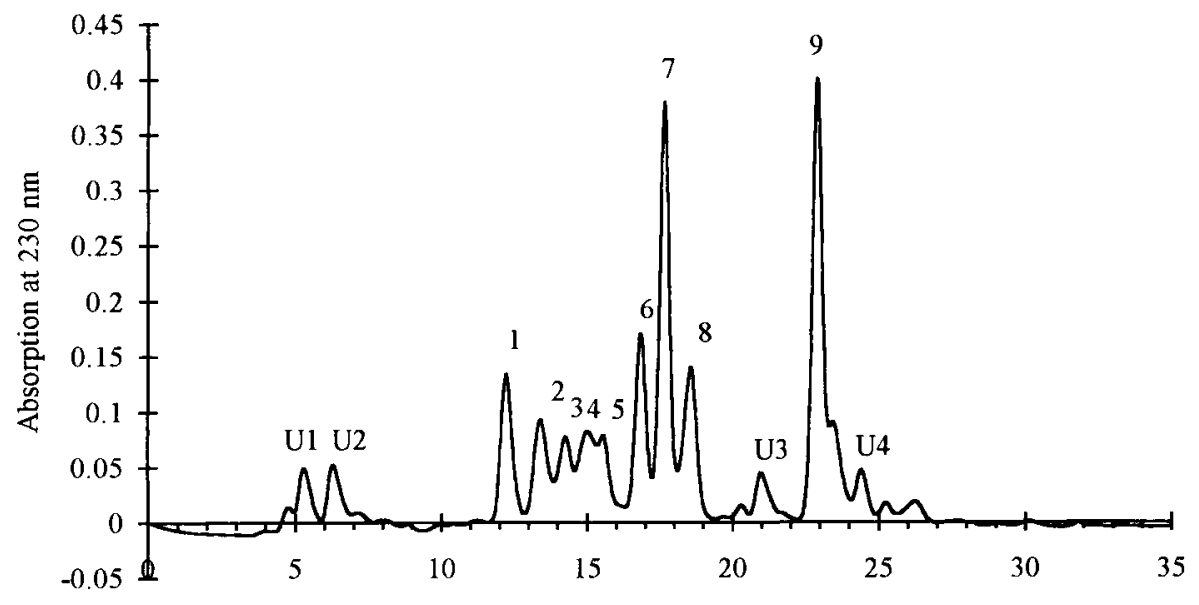

Run time (minutes)

Fig 1. Chromatogram of separated ellagitannins from a water extraction of oak heartwood. U1-U4:Unidentified possible ellagitannins; 1: Roburin A (vescalagin-vescalagin); 2: Roburin B (vescalagin-vescalagin-lyxose); 3: Roburin C (vescalagin-vescalagin-xylose); 4: Gallic acid; 5: Grandinin (vescalaginlyxose); 6: Roburin D (vescalagin-castalagin); 7: Vescalagin; 8: Roburin E (vescalagin-xylose); 9: Castalagin. The retention time of gallic acid was found to be highly variable relative to the other peaks, occasionally interfering with roburin B. Identity was always checked by examination of spectra and/or coinjection with an authentic standard. The possible tannins $U 1$ and $U 2$ were tentatively identified as vescalin and castalin on the basis of their appearance in standard solutions of castalagin and vescalagin that had been stored over several months. 
HPLC or GC (Puech et al, 1990; Peng et al, 1991; Scalbert, 1992). The concentration of insoluble ellagitannins was determined in wood samples from one Limousin and one Troncais stave. Three replicate extractions of wood samples from each stave were carried out in Teflon tubes, using the solvent and conditions described previously. After extraction the solvent was removed with a syringe fixed with a fine hypodermic needle. The samples were air-dried and re-weighed before $5 \mathrm{~mL}$ of $\mathrm{MeOH} / \mathrm{HCl} 6 \mathrm{M}$ 9/1 v/v, containing $0.5 \mathrm{mg} 1$-naphthol (Aldrich) was added to each of the residues. After heating at $120{ }^{\circ} \mathrm{C}$ for 160 minutes, the solutions were then filtered and analysed by HPLC to determine quantities of ellagic acid, which were expressed as castalagin equivalents (Peng et al, 1991; Viriot et al, 1994).

Column: Waters reverse-phase $\mathrm{C} 18$; $260 \times 4 \mathrm{~mm}$; Spherisorb packing. Injection volume: $20 \mu \mathrm{L}$. Detection: at $280 \mathrm{~nm}(190-400 \mathrm{~nm}$ for identification). Internal standard: 1-naphthol (Aldrich). Gradient: The following solvents were used: $\mathrm{H}_{2} \mathrm{O} / \mathrm{H}_{3} \mathrm{PO}_{4} 99 / 1 \mathrm{v} / \mathrm{v}$ (solvent $\mathrm{A}$ ) and $\mathrm{MeOH} / \mathrm{H}_{3} \mathrm{PO}_{4} 99 / 1 \mathrm{v} / \mathrm{v}$ (solvent $\mathrm{B}$ ) to run a linear gradient from 0 to $100 \%$ solvent $B$ over 30 minutes with a flow rate of $1 \mathrm{~mL} / \mathrm{min}$.

\section{Measurement of wood colour and ring width}

Ten measurements of wood colour were made across a cleanly cut transverse section (radial face) of each French oak stave. Mean ring widths were also determined. Colour was measured with a Colorquest Hunterlab spectrocolourimeter using the CIE standard illuminant D65 (corresponding to daylight under an overcast sky) and an observation angle of $10^{\circ}$. This measured the percentage of reflected light at 32 wavelengths, distributed at $10 \mathrm{~nm}$ intervals between 400 and $710 \mathrm{~nm}$. The reflectance spectrum was represented by the CIELab system, which has been widely used in previous studies of wood colour (eg, Janin, 1987; Klumpers et al, 1994, 1993; Charrier et al, 1995). The system represents colour using $\mathrm{L}$ (lightness) and the chromatic coordinates $a^{*}$ (red-green axis) and $b^{*}$ (blue-yellow axis). Additional parameters used to describe colour may be derived from these variables. These include the angle of taint or hue, $\mathrm{h}=$ arc$\tan \left(\mathrm{b}^{\star} / \mathrm{a}^{\star}\right)$ and colour saturation :

$$
C^{*}=\sqrt{a^{* 2}+b^{* 2}}
$$

\section{RESULTS}

\section{Variation of ellagitannins with heartwood age}

Due to the overlap of the peaks for gallic acid and roburin B in some samples, both these were excluded from analyses. The variations in ellagitannin concentrations are illustrated in figure 2 . The results indicate that as well as a general decline in ellagitannins, the individual tannins respond differently during ageing.

Vescalagin, the most abundant ellagitannin in outer heartwood, is seen to decrease rapidly during the first 20 or 30 years of ageing, after which the decline lessens or even ceases. Castalagin, less abundant than vescalagin in outer heartwood, declines at a slower and more constant rate, becoming the most abundant tannin in older heartwood. The other ellagitannins show more diverse patterns of variation. The dimer roburin $\mathrm{D}$ shows a similar pattern to vescalagin, which contrasts with the variation of roburins $A$ and $C$. Roburin $A$ increases in concentration during the first 10 years of ageing and roburin $\mathrm{C}$ over the first 30 years, before each declines again in older wood. Grandinin and roburin E show less clear patterns, but in general concentrations remain approximately constant during the first 30 years before declining.

The concentration of ellagitannins in each heartwood zone was then expressed as a percentage of that in the youngest heartwood (years 0-5). The means and standard error bars for all four trees are shown in figure 3 . This displays a logarithmic decline with heartwood age. The following simple linear model was fitted:

$$
\ln \left(T_{a} / T_{o h}\right)=b a
$$

where $a$ is the heartwood age; $T_{a}$ is the concentration of ellagitannins at age $a$ and $T_{\text {oh }}$ where $a=0$.

This gives an estimate for $b$ of -0.0219 with a standard error of 0.0007 and an $R^{2}$ 

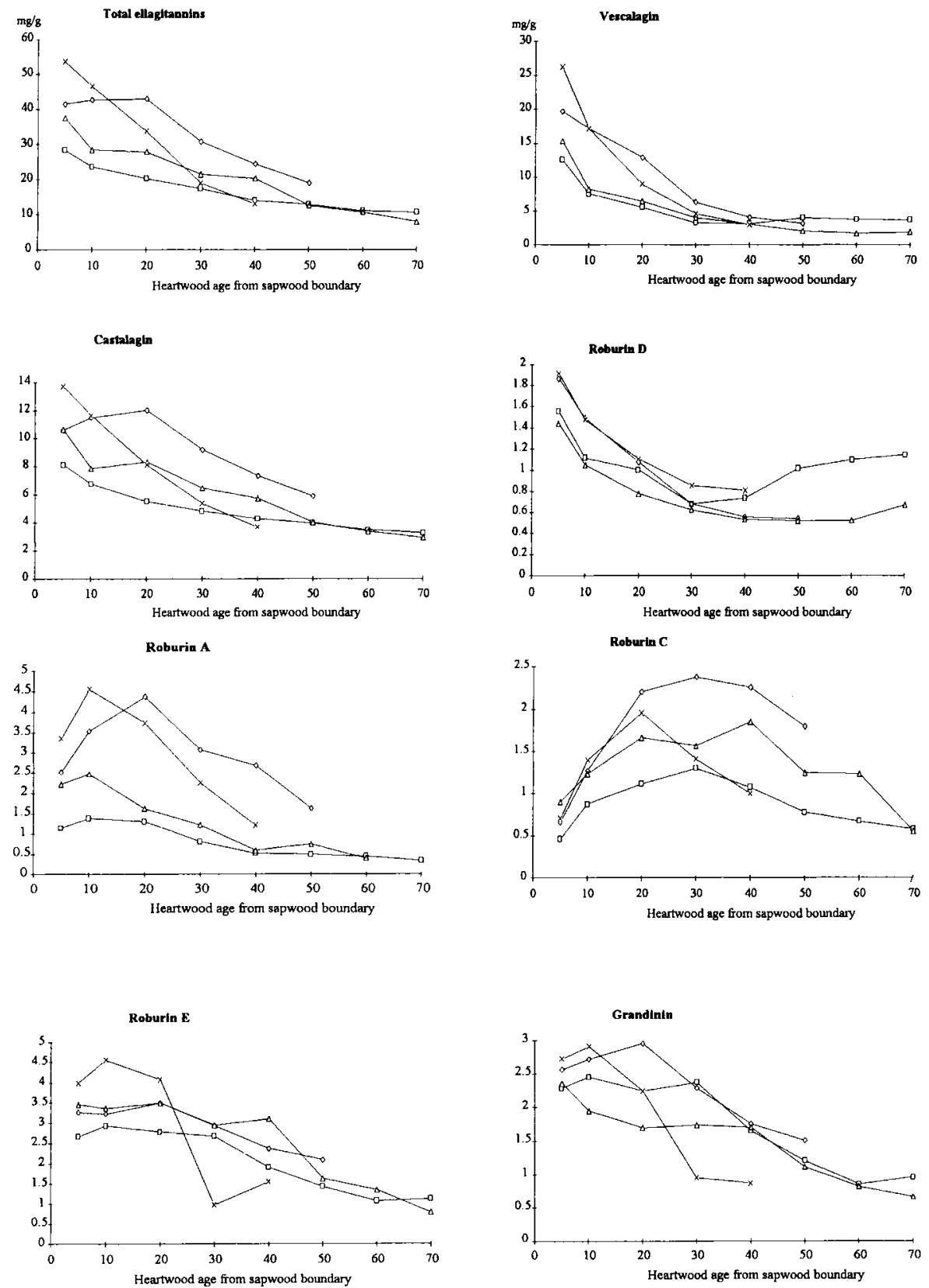

Fig 2. Concentration of ellagitannins $(\mathrm{mg} / \mathrm{g})$ between heartwood zones of different ages in four trees.

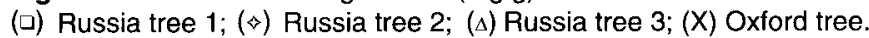




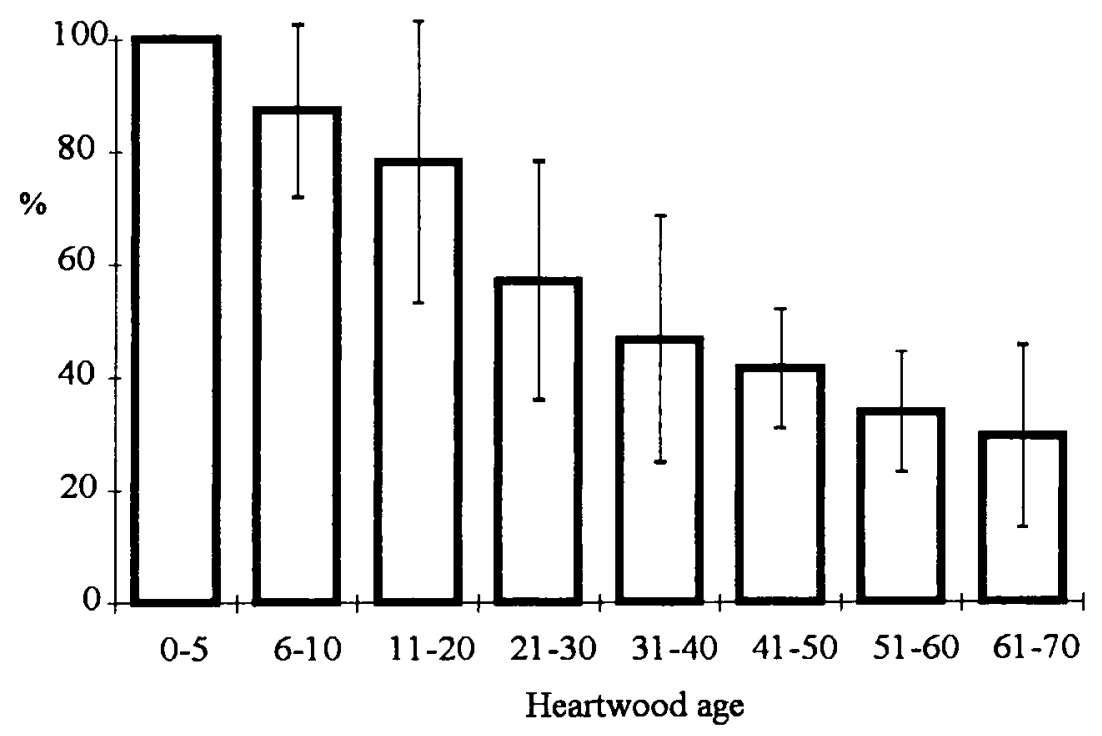

Fig 3. Mean total ellagitannin concentrations (and $2 \mathrm{x}$ standard error bars), extracted from heartwood regions of different ages, from four trees, expressed as percentages of the concentrations found in the youngest heartwood zone (years $0-5$ ).

of 0.988 . Therefore, if one knows the level of tannins in the outermost heartwood, that in the heartwood of age a may be estimated by $T_{a}=T_{\text {oh }} / e^{0.0219 a}$.

\section{Between- and within-forest variation}

Figure 4 shows the concentration of ellagitannins in north -and south-facing staves of each tree plotted on opposing axes. As well as illustrating the difference between the two forests, the fact that most of the points lie approximately along a gradient of one indicates that there were similar concentrations in each of the staves from the same tree. The lower variation among samples from the Tronçais forest than those from the Limousin is also apparent and the data were log-transformed, resulting in more homogeneous variances.

A balanced, nested analysis of variance was used to compare the variation between and within trees and forests. The results and the large proportion of variance explained by between-tree and between-forest variation are shown in table II. The two samples from each tree were treated as random replicates for this analysis. Due to one tree having only a single replicate, both this tree and the data of a random tree from the other site were removed from analysis, reducing the total degrees of freedom to 37 within each site.

By calculating Spearman correlation coefficients, highly significant correlations were found between all the individual ellagitannins. The strongest correlation was that between total phenolics and total ellagitannins, with an $R$ value of 0.99 . This suggests that the Folin Denis method is an effective means of comparing the tannin contents of oak wood, supporting results described by Puech et al (1990). Viriot et al (1995) reported that heartwood ellagitannin content determined by the Folin method was less affected by heartwood age. Table II shows that the difference between the forests was only slightly lower for total phenols than for total ellagitannins. 


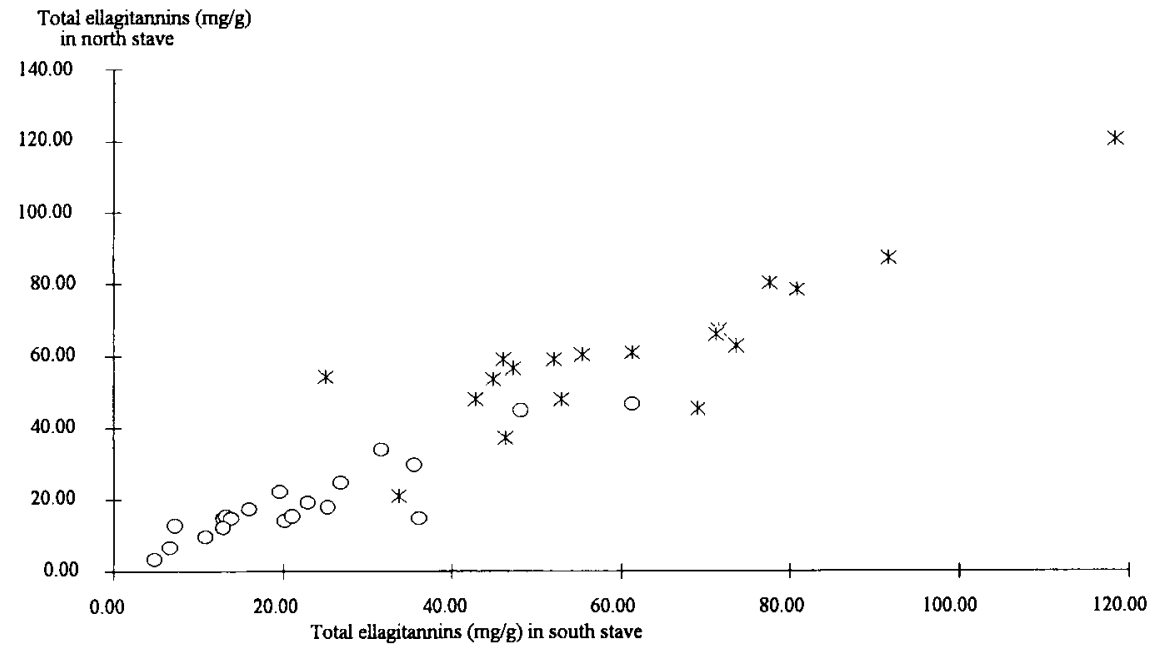

Fig 4. The concentrations of total soluble ellagitannins in trees from Limousin ( ${ }^{\star}$ ) and Tronçais (o) forests. For each tree the amount of ellagitannins extracted from north- and south-facing staves are plotted along the opposing axes.

Table II. Mean forest values of wood properties, percentage variance components (\% var) and probabilities from analyses of variance.

\begin{tabular}{|c|c|c|c|c|c|c|c|c|}
\hline \multirow[t]{2}{*}{ Character } & \multicolumn{2}{|c|}{ Limousin } & \multicolumn{2}{|c|}{ Tronçais } & \multicolumn{2}{|c|}{ Between forests } & \multicolumn{2}{|c|}{$\begin{array}{c}\text { Between trees } \\
\text { within forests }\end{array}$} \\
\hline & Mean & $S E$ & Mean & $S E$ & $\%$ var & $P$ & $\%$ var & $P$ \\
\hline Unknown 1 & 1.42 & 0.10 & 0.84 & 0.09 & 28 & $\star \star *$ & 48 & $\star \star \star$ \\
\hline Unknown 2 & 1.49 & 0.09 & 1.12 & 0.11 & 13 & * & 65 & $\star \star \star$ \\
\hline Roburin A & 4.24 & 0.36 & 0.76 & 0.10 & 68 & $* * *$ & 23 & $\star \star \star$ \\
\hline Roburin B & 2.92 & 0.18 & 1.44 & 0.18 & 44 & $\star \star \star \star$ & 36 & 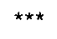 \\
\hline Roburin C & 1.94 & 0.24 & 1.08 & 0.20 & 15 & * & 51 & $\star \star \star$ \\
\hline Grandinin & 3.82 & 0.19 & 1.90 & 0.18 & 54 & $\star \star \star \star ~$ & 37 & $\star \star \star$ \\
\hline Roburin D & 4.92 & 0.37 & 1.58 & 0.23 & 58 & $\star \star \star \star$ & 27 & $\star \star \star \star$ \\
\hline Vescalagin & 16.68 & 1.16 & 2.79 & 0.25 & 77 & $\star \star * *$ & 19 & $* * *$ \\
\hline Roburin E & 5.80 & 0.30 & 2.82 & 0.30 & 53 & $\star * * *$ & 35 & $\star * *$ \\
\hline Unknown 3 & 1.36 & 0.13 & 0.37 & 0.04 & 56 & $\star \star \star$ & 29 & $\star \star \star$ \\
\hline Castalagin & 15.13 & 0.86 & 4.74 & 0.49 & 72 & $* * *$ & 24 & $\star \star \star *$ \\
\hline Unknown 4 & 1.50 & 0.10 & 0.79 & 0.11 & 33 & $\star \star \star \star$ & 36 & $\star \star \star \star$ \\
\hline Total tannins & 61.21 & 3.35 & 20.24 & 2.00 & 72 & $\star \star \star$ & 24 & $\star \star \star$ \\
\hline Total phenols & 54.53 & 1.80 & 27.78 & 2.02 & 70 & $\star \star \star$ & 25 & 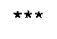 \\
\hline Ring width & 3.06 & 0.15 & 1.24 & 0.06 & 76 & $\star \star \star \star$ & 9 & $\star \star$ \\
\hline
\end{tabular}

${ }^{\star} P=0.05 ;{ }^{\star \star} P=0.01 ;{ }^{\star \star \star} P=0.001$. All tannin concentrations in $\mathrm{mg} / \mathrm{g}$ wood; ring widths in $\mathrm{mm}$. 


\section{Wood colour and ring widths}

Of the three variables lightness $\left(L^{*}\right), a^{*}$ and $\mathrm{b}^{\star}$ used to define wood colour, lightness varied most. However, analyses of variance found that only $b^{*}$ and the derived variables hue and colour saturation varied significantly between the two forests, while significant variation between trees and samples was found for all three variables. Variance components (see table III) show that the between-forest variation accounted for a relatively small amount of the total variation of wood colour. Greater between forest variation was found for ring width, with the Limousin samples having much wider rings than those from Tronçais (table II). Among the wood colour parameters, the variable $b^{*}$ (blue-yellow axis) correlated most strongly with tannin content both separately for each forest and when the data for the two are grouped ( $R$ grouped $=0.640$ ). Despite scatter this trend is perceptible in figure 5. Similar correlations were found between total tannins and both hue and colour saturation which correlate strongly with $b^{*}$.

\section{Composition of ellagitannins}

In order to test whether the composition of ellagitannins varied between sites, the percentage of each ellagitannin was calculated in relation to total soluble ellagitan- nins. A nested analysis of variance was carried out on arcsine-transformed percentage data. A nonparametric comparison of the two sites was also carried out by a Wilcoxon two-sample test of rank sums (SAS Institute Inc, 1985; Neave and Worthington, 1988). Both the parametric and nonparametric tests found significant differences between the two sites for most of the ellagitannins (table IV). The most prominent difference was the lower proportion of vescalagin in the Tronçais samples.

It has been previously observed that the proportion of vescalagin varies with heartwood age. The results suggest that the Tronçais samples are, on average, cut from older heartwood than the Limousin samples. This is confirmed by the slower growth, as indicated by narrower ring widths, of Tronçais trees which results in the average heartwood age of these samples being greater than Limousin samples.

\section{Influence of wood age on soluble ellagitannins}

One could propose that the difference in tannin concentrations between the two forests is simply due to the difference in heartwood age of the samples. Greater insolubulization or hydrolysis of soluble ellagitannins may have occurred in the older samples from Tronçais.

Table III. Forest means, variance components (\% var) and probabilities of significant variation.

\begin{tabular}{|c|c|c|c|c|c|c|c|c|c|c|}
\hline \multirow[t]{2}{*}{ Character } & \multicolumn{2}{|c|}{$\begin{array}{l}\text { Limousin } \\
(\mathrm{n}=117)\end{array}$} & \multicolumn{2}{|c|}{$\begin{array}{l}\text { Tronçais } \\
(n=120)\end{array}$} & \multicolumn{2}{|c|}{$\begin{array}{c}\text { Between } \\
\text { forests } \\
(d f=1)\end{array}$} & \multicolumn{2}{|c|}{$\begin{array}{c}\text { Between trees } \\
\text { in forests } \\
(d f=36)\end{array}$} & \multicolumn{2}{|c|}{$\begin{array}{c}\text { Between } \\
\text { samples withir } \\
\text { trees }(d f=38)\end{array}$} \\
\hline & Mean & $S E$ & Mean & $S E$ & $\%$ var & $P$ & $\%$ var & $\mathrm{P}$ & $\%$ var & $P$ \\
\hline$L^{*}$ & 61.07 & 0.18 & 60.44 & 0.28 & 0.4 & 0.298 & 31.6 & * & 50.6 & $\star * \star *$ \\
\hline$a^{*}$ & 11.25 & 0.05 & 11.40 & 0.05 & 0.0 & 0.367 & 42.6 & ** & 46.7 & 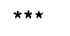 \\
\hline$b^{*}$ & 23.46 & 0.09 & 22.68 & 0.09 & 18.5 & * & 43.4 & $\star * \star *$ & 23.0 & $* * *$ \\
\hline Hue h & 1.123 & 0.001 & 1.104 & 0.001 & 42.6 & $\star \star \star$ & 32.0 & 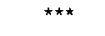 & 19.3 & $\star \star \star \star ~$ \\
\hline Saturation C & 264.4 & 2.13 & 259.1 & 2.24 & 10.3 & * & 44.9 & 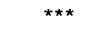 & 29.0 & 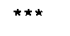 \\
\hline
\end{tabular}

$\mathrm{df}=$ degrees of freedom; ${ }^{\star} P=0.05 ;{ }^{\star \star} P=0.01 ;{ }^{\star \star *} P=0.001$. 


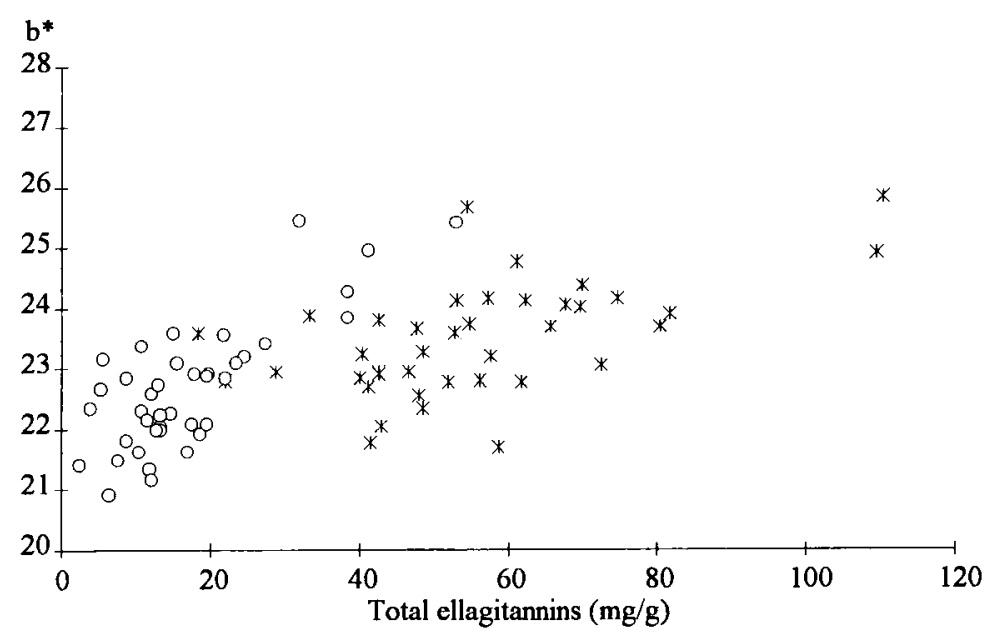

Fig 5. Wood colour variable $b^{*}$ versus total soluble ellagitannins measured in a total of 80 samples from 40 trees from Limousin $\left(^{*}\right)$ and Tronçais $(0)$ forests.

Table IV. Parametric and nonparametric tests for differences between forest and tree means of the concentration of individual ellagitannins expressed as a percentage of the ellagitannin concentration.

\begin{tabular}{|c|c|c|c|c|c|}
\hline \multirow[t]{2}{*}{ Ellagitannin } & \multicolumn{2}{|c|}{ Mean percentage } & \multirow{2}{*}{$\begin{array}{c}\text { Wilcoxon two } \\
\text { sample text } \\
\mathrm{P} \text { of between } \\
\text { site }\end{array}$} & \multicolumn{2}{|c|}{ Anova of arcsine transformed data } \\
\hline & Limousin & Tronçais & & $\begin{array}{c}\mathrm{P} \text { of between } \\
\text { site }\end{array}$ & $\begin{array}{c}\text { Between trees } \\
\text { within site }\end{array}$ \\
\hline Unknown 1 & 2.4 & 4.3 & 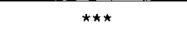 & $* * * *$ & $\pi \star *$ \\
\hline Unknown 2 & 2.6 & 5.7 & $* * *$ & $* * *$ & $\star \star \star \star$ \\
\hline Roburin 2 & 6.6 & 3.3 & $* \star \star \star$ & $* * *$ & ns \\
\hline Roburin B & 4.9 & 6.4 & $* * *$ & $* *$ & $\mathrm{~ns}$ \\
\hline Roburin C & 3.3 & 4.5 & ns & ns & $* *$ \\
\hline Grandinin & 6.5 & 10.0 & $* \star \star$ & *** & ns \\
\hline Roburin D & 7.8 & 6.9 & $\star \star$ & ns & ns \\
\hline Vescalagin & 26.7 & 14.9 & $\star \star \star \star$ & 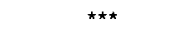 & $\star \star \star \star$ \\
\hline Roburin $\mathrm{E}$ & 9.8 & 14.0 & $\star \star \star$ & 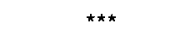 & ns \\
\hline Unknown 3 & 2.1 & 1.9 & ns & ns & $\star *$ \\
\hline Castalagin & 24.7 & 24.8 & ns & ns & ns \\
\hline Unknown 4 & 2.5 & 3.3 & $\star \star \star$ & $\star \star$ & $\mathrm{ns}$ \\
\hline
\end{tabular}

${ }^{*} P=0.05 ;{ }^{* *} P=0.01 ;{ }^{* * *} P=0.001 ;$ ns: $P>0.05$. 
Table V. Estimated heartwood age of samples and soluble tannins in the youngest heartwood $(\mathrm{mg} / \mathrm{g}$ wood) and percentage remaining in samples (\%).

\begin{tabular}{lccc}
\hline Forest & $\begin{array}{c}\text { Mean stave } \\
\text { heartwood age }\end{array}$ & $\begin{array}{c}\text { Ellagitannins in } \\
\text { young heartwood }\end{array}$ & $\% \mathrm{r}$ \\
\hline Limousin & 20 & 95 & 67.8 \\
Tronçais & 48 & 58 & 38.9 \\
\hline
\end{tabular}

See text for method of estimation.

Two different approaches were used to address this possibility.

\section{Estimating soluble tannin decline due to heartwood age}

The heartwood age of samples from each forest can be estimated from ring widths. If one assumes that all staves are $7 \mathrm{~cm}$ across in transverse section with the nearest edge cut $2.5 \mathrm{~cm}$ from the sapwood boundary, one can calculate average heartwood age assuming constant annual growth equal to the mean ring widths for each forest (see table $V$ ).

Using this estimate of mean heartwood age as $a$ and the mean total ellagitannins found in samples from each forest (table II) as $T_{a}$, the concentrations of tannins in the new, outermost heartwood $T_{\text {oh }}$ can be estimated using the model developed earlier, where $T_{o h}=T_{a} e^{(0.0219 a)}$.

Table $V$ shows that there remains a large difference between the two forests in the estimated soluble ellagitannins of new heartwood.

\section{Measurement of insoluble tannins in two samples}

Table VI gives the mean concentrations of insoluble ellagitannins remaining in samples of Limousin and Tronçais wood after water extractions. The concentration of insoluble ellagitannins is probably slightly overestimated as the free ellagic acid present in the wood, formed from the natural hydrolysis of ellagitannins, was not measured. Although slightly soluble in water the majority of free acid will have remained in wood residues. Viriot et al (1994) calculated the concentration of ellagic acid at the sapwood/heartwood boundary as representing $10 \%$ of the total ellagitannins, with $1 \%$ of ellagitannins hydrolyzed into ellagic acid every following 10 years. The difference in total ellagitannins between the two samples is greater than that indicated from the earlier calculations, suggesting that the earlier assumptions over-rather than underestimated the difference in heartwood age.

Overall, these results suggest that the differences in tannin concentrations between

Table VI. Mean amounts of soluble and insoluble ellagitannins $(\mathrm{mg} / \mathrm{g})$ from three extractions, followed by degradation in alcohol-acid solutions from a single stave of each of the Limousin and Tronçais wood.

\begin{tabular}{lcccc}
\hline Forest & \multirow{2}{*}{$\begin{array}{c}\text { Total soluble } \\
\text { ellagitannins }\end{array}$} & \multicolumn{2}{c}{ Insoluble ellagitannins } & Total ellagitannins \\
\cline { 3 - 4 } & & Means $(n=3)$ & $S E$ & \\
\hline Limousin & 87.1 & 11.5 & 0.78 & 98.5 \\
Tronçais & 12.8 & 6.6 & 1.20 & 19.3
\end{tabular}

SE: standard error. 
the forests cannot be explained solely by a difference in the heartwood age of the samples, if one assumes that the rate of reactions which occur during ageing is similar in all trees.

\section{DISCUSSION}

The increase in the concentrations of roburins $A, C$ and possibly other dimers during the first 10-30 years of ageing are due to their synthesis from other tannins (Viriot et al, 1994). This implies that the monomers vescalagin and castalagin may transform directly or indirectly to dimers. The rapid decline in vescalagin corresponds with an increase in concentrations of these dimers. Roburin D (vescalagincastalagin) increases later than roburins $A$ and $C$ possibly due to the slower decline in castalagin. These results from four trees of Q robur support those of Viriot et al (1994), which were taken from measurements of single trees of $Q$ petraea and Castanea sativa.

A high degree of variation in the soluble tannins is demonstrated between the two forests. The low within-tree variation was probably due to the restrictions placed on the sampling, with samples taken of only cask-quality wood from the outer heartwood near the base of each tree. The forests sampled were selected to correspond to contrasting criteria used within the cooperage industry to select wood. Therefore the relative proportion of variation explained by between-forest differences should be treated as an upper limit of the variation that could feasibly be selected for by coopers. Singleton (1974) found that tannin concentrations were greater in the earlywood compared to the latewood of annual rings and therefore proposed that oak wood with narrow rings would contain higher levels of tannins due to the higher proportion of earlywood. Hillis (1975) also suggested that slow growing trees would contain higher levels of heartwood poly- phenols due to the greater 'stress' they were under. However, the results reported here give no support to these hypotheses, with higher levels found in the more rapidly grown Limousin wood.

Rapid growth due to a more intense thinning regime are characteristic of the mostly privately owned forests in the Limousin region. More slowly grown oaks will be felled at a later age and the stave wood from such trees will, on average, be older, even if cut from the same location within the tree. Due to the rapid decline in soluble tannins observed in the first 20 years of heartwood ageing, this might significantly influence the average tannin content. Samples used in this study comprised between 12-50 years of heartwood growth, depending on ring widths. However, the results and calculations presented here strongly suggest that differences in extracted ellagitannins cannot be explained solely by differences in wood age. This supports the findings of other studies (Mosedale and Savill 1996; Mosedale et al, 1996) which have found significant differences between species, provenances and clones of young oaks in the total ellagitannin and phenolic content of outer heartwood of the same age. This is not to say that the differences may not be due to variation in the rates of reactions which occur during heartwood ageing. The rate of oxidation reactions occurring during ageing could, for example, be determined by variation between trees and sites in the availability of metal cations. Figures 2 and 3 show that even among the four trees used to calculate the model there was variation in the rate of ellagitannin decline with heartwood age.

It has been previously observed that inner heartwood is darker and colour saturation more pronounced than outer heartwood, and that tannins may play a role in the formation of heartwood colour (Klumpers and Janin, 1992; Klumpers et al, 1993, 1994). The results reported here support the notion of a relationship between wood colour 
and extractive content; however, there is no means of determining whether or not the correlation between total ellagitannins and the wood colour parameter $b^{*}$ is entirely explained by the different heartwood age of samples.

The difference in ellagitannin content may be explained by different rates of the reactions taking place during ageing, or by a difference in the initial concentrations laid down in the heartwood. One could alternatively propose that it is due to variation of other heartwood constituents which influence ellagitannin measurement, although the similar differences in total phenolics makes this less likely. The two forests differed in many ways and this makes it impossible to suggest what might be the cause for the large differences found in tannin concentrations through whatever mechanism. However, the careful sampling and treatment of wood samples after felling, and the large proportion of variation found between the forests, suggests that factors beyond the local forest environment influence wood tannin concentrations. Recent studies (Mosedale and Savill, 1996; Mosedale et al, 1996) have indicated that ellagitannin content is under strong genetic control and that $Q$ robur trees have generally greater concentrations than $Q$ petraea. The results of this study are in agreement with this observation, with higher concentrations found in the heartwood of the predominantly $Q$ robur Limousin trees.

\section{ACKNOWLEDGMENTS}

The authors would like to thank A Ford of United Distillers for his assistance with methodologies and $C$ Houssement at INRA, Champenoux for colour measurements. G Roy and JL Giraud at Tonnellerie Taransaud were invaluable in acquiring French oak samples and $\operatorname{Pr} V$ Vereshchagina and her colleagues at the University of Perm and at Voronezh provided samples from Russia. We would also like to thank the referees of this paper for their constructive comments. The work was funded by United Distillers.

\section{REFERENCES}

AOAC (1984) Official Methods of Analysis, 14thed. Sections 9.110-9.112. Arlington, VA, USA

AOAC (1990) Official Methods of Analysis, 15th edition. Section 952.03. Arlington, VA, USA

Charrier B, Janin G, Haluk JP, Mosedale JR (1995) Colour and visual characteristics of moon rings in oak wood. Holzforschung 49, 287-292

Hillis WE (1975) Ethylene and extraneous material formation in wood tissues. Phytochemistry 114, 25592562

Janin G (1987) Mesure de la couleur du bois. Intérêt forestier et industriel. Ann Sci For 44, 455-472

Klumpers J, Janin G (1992) Influence of age and annual ring width on the wood colour of oaks. Holz als rohund werkstoff $50,1-5$

Klumpers J, Janin G, Becker M, Levy G (1993) The influences of age, extractive content and soil water on wood colour in oak: the possible genetic determination of wood colour. Ann Sci For 50 (suppl 1), 166-285

Klumpers J, Scalbert A, Janin G (1994) Ellagitannins in European oak wood - polymerization during wood ageing. Phytochemistry 36, 1249-1252

Marco J, Artajona J, Larrechi MS, Rius FX (1994) Relationship between geographical origin and chemical composition of wood for oak barrels. Am J Enology Viticulture 45, 192-200

Miller DP, Howell GS, Michaelis CS, Dickmann DI (1992) The content of phenolic acid and aldehyde flavor components of white oak as affected by site and species. Am J Enology Viticulture 43, 333-338

Mosedale JR (1995) Effects of oak wood on the maturation of alcoholic beverages with particular reference to whisky. Forestry 68, 203-230

Mosedale JR, Savill PS (1996) Variation of heartwood pehnolics and oak lactones between the species and phenological types of Quercus petraea and $Q$ robur. Forestry 69, 48-55

Mosedale JR, Charrier B, Janin G (1996) Genetic control of wood colour, density and heartwood ellagitannin concentration in European oak (Quercus petraea and $Q$ robur). Forestry $69,111-124$

Neave HR, Worthington PL (1988) Distribution Free Tests. Unwin Hyman, London, UK

Peng S, Scalbert A, Monties B (1991) Insoluble ellagitannins in Castanea sativa and Quercus petraea woods. Phytochemistry 30, 375-378

Puech JL (1984) Characteristics of oak wood and biochemical aspects of Armagnac aging. Am J Enology Viticulture $35,77-81$

Puech JL, Rabier P, Bories-Azeau J, Sarni F, Moutounet M (1990) Determination of ellagitannins in extracts of oak wood and in distilled beverages matured in oak barrels. J Ass Off Anal Chem 73, 498-501

Quinn, MK, Singleton VL (1985) Isolation and identification of ellagitannins from white oak wood and an estimation of their roles in wine. Am J Enology Viticulture $36,148-155$ 
Rous C, Alderson B (1983) Phenolic extraction curves for white wine aged in French and American oak barrels. Am J Enology Viticulture 34, 211-215

SAS Institute Inc (1985) SAS User's Guide: Statistics, Version 5, Edition, Cary, NC, USA

Scalbert A (1992) Quantitative methods for the estimation of tannins in plant tissues. In: Plant Polyphenols: Synthesis, Properties, Significance (RW Hemingway, PE Laks, eds), Basic Life Sciences, Plenum Press, New York, 59, 259-280

Scalbert A, Monties B, Favre JL (1988) Polyphenols of Quercus robur. adult tree and in vitro growth calli and shoots. Phytochemistry 27, 3483-3488

Scalbert A, Duval L, Peng S, Monties B (1990) Polyphenols of Quercus robur. preparative isolation by low pressure and high pressure liquid chromatography of heartwood ellagitannins. J Chromatography 502 , 107-119

Singleton VL (1974) Some aspects of the wooden container as a factor in wine maturation. In: Chemistry of Wine Making (AD Webb, ed), American Chemist's Society, Washington, DC, USA, 254-277

Viriot C, Scalbert A, Lapierre C, Moutounet M (1993) Ellagitannins and lignins in ageing of spirits in oak barrels. J Agric Food Chem 41, 1872-1879

Viriot C, Scalbert A, Hervé du Penhoat CLM, Moutounet $M$ (1994) Ellagitannins in woods of sessile oak and sweet chestnut-dimerization and hydrolysis during wood ageing. Phytochemistry 36, 1253-1260

Zobel BJ, Talbert JT (1984) Applied Forest Tree Improvement. John Wiley and Sons, New York, USA 